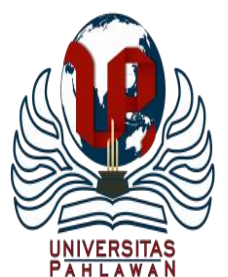

Jurnal Basicedu Volume 4 Nomor 4 Tahun 2020 Halaman 1388 - 1397

JURNAL BASICEDU

Research \& Learning in Elementary Education

https://jbasic.org/index.php/basicedu

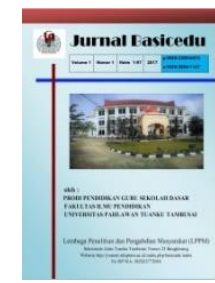

\title{
Improving Science Learning Activites And Outcomes By Using Problem Based Learning Model At Elementary School
}

\author{
Ahmad Saleh ${ }^{1}$, Yuni Ahda ${ }^{2}$, Yanti Fitria ${ }^{3}$ \\ Postgraduate Student of Pendidikan Dasar; Universitas Negeri Padang ${ }^{1}$ \\ Lecturer; Universitas Negeri Padang 2,3 \\ E-mail : $\underline{\text { salehp2dafa@gmail.com }} \underline{\text { ahda_yuni@pps.unp.ac.id }}^{2}$ yantifitria@ fip.unp.ac.id $^{3}$
}

\begin{abstract}
Science learning requires direct experience in order to develop the ability to explore and understand the natural surroundings scientifically. So far in elementary school at Bukittinggi, the process of learning science only memorizes facts, principles or theories. In science learning, students are not involved in finding or applying their own ideas and they do not instill the values contained in the learning. The science learning process in classroom is not yet fully in accordance with the demands of the curriculum. The teacher provides more material in the textbook without relating it to students' daily problems that are in accordance with the material, thus causing less interesting in learning. The teacher also has not actively involved all students in learning and emphasizes learning only on students who are smarter. The purpose of this study was to increase the activity and learning outcomes of science learning by using a problem-based learning model in SDN 11 Aur Kuning Bukittinggi, West Sumatra. This classroom action research was conducted in 2 cycles with the research subjects of grade IV students with totalling 25 people. The research data were collected through observation and tests. The effectiveness of actions in each cycle from the results of observations and tests is described and then reflected to take corrective action in the next cycle. In science learning, students' learning activities were observed, namely: visual activities, oral activities, writing activities, motoric activities and emotional activities. The research findings show that the problem-based learning model can increase student activity and learning outcomes.
\end{abstract}

Keywords: PBL, students' activities, students' learning outcomes

Copyright (c) 2020 Ahmad Saleh, Yuni Ahda, Yanti Fitria

$\square$ Corresponding author

Address : Bukittinggi West Sumatra Indonesia

ISSN 2580-3735 (Media Cetak)

Email : salehp2dafa@gmail.com

ISSN 2580-1147 (Media Online)

Phone : +6285274079004

DOI: https://doi.org/10.31004/basicedu.v4i4.578 
1389 Improving Science Learning Activites And Outcomes By Using Problem Based Learning Model At Elementary School - Ahmad Saleh, Yuni Ahda, Yanti Fitria

DOI: https://doi.org/10.31004/basicedu.v4i4.578

\section{NTRODUCTION}

The development of the education sector is one of the priorities in national development in Indonesia. This is understandable, considering that national education has very important functions and objectives. In line with national development policies, the government has made a lot of attention and efforts in order to improve the quality of education in Indonesia, including: improving the curriculum in schools, improving the quality of teachers, school-based management, improving educational facilities and so on (Murni Eva Marlina, 2013), (Nurmalasari et al., 2016). Although some of these efforts have yielded results, they have not been optimal, including in the implementation of the learning process and the achievement of student learning outcomes at every level of education.

Science is one of the subjects in elementary schools that supports science and technology, where the science learning process requires direct experience in order to develop the ability to explore and understand the natural surroundings (Nurfidianty, Ashadi, \& Mulyani, 2015); (Sari et al., 2019). Science as one of the subjects in elementary school is a program to instil and develop knowledge, skills and attitudes of scientific values in students, as well as a sense of love and respect for the greatness of God Almighty. Science is not a rote subject, but a lesson that provides many opportunities for students to make various observations and exercises, especially those related to developing the ability to carry out learning activities (Widya Sukmana, 2018), (Dwi \& Anitah, 2018). To increase students' activeness and understanding of science learning, students need to get used to solving problems, finding something useful for themselves, and wrestling with ideas. The knowledge gained by memorizing can only last a short period of time, while the knowledge gained from "finding it yourself (inquiry)" can last a long time and the learning process will be more meaningful for students.

In fact, science learning carried out in elementary schools is not in accordance with the demands of the curriculum in force in Indonesia, which is carried out by scientific inquiry. So far, the process of learning science in elementary school only memorizes facts, principles or theories. In science learning students are not involved in finding or applying their own ideas, and they do not instil the values contained in the learning. Indonesia, for learning achievement, science ability is in the $32^{\text {nd }}$ position out of 42 countries and $40^{\text {th }}$ for mathematics learning achievement (Juleha, Nugraha, \& Feranie, 2019). This learning achievement is seen based on the results of the national final exam. Most of the students complained that science learning was boring and scary. This is related to the teaching methods that are less attractive and the provision of science questions that are less relevant to everyday life. So that science lessons that are expected to build human logic and understand the environment are not achieved. One of the weaknesses in achieving quality science learning is related to the implementation of learning, such the weak process that occurs in learning activities. The learning process that has been taking place has not 
1390 Improving Science Learning Activites And Outcomes By Using Problem Based Learning Model At Elementary School - Ahmad Saleh, Yuni Ahda, Yanti Fitria

DOI: https://doi.org/10.31004/basicedu.v4i4.578

encouraged student activeness in developing the knowledge they have, because students are still given direct knowledge by the teacher. The teacher provides more material in the textbook without relating it to students' daily problems that are in accordance with the material so that learning is less interesting. The teacher also has not actively involved students in learning and emphasizes learning only for smart students.

Based on the problems above, it is necessary to take an action to improve the quality of the learning process which is expected to increase student activity and learning outcomes. One of the constructivism-based scientific learning models that can be applied is Problem Based Learning (PBL). This learning model can be applied to science learning to provide meaningful learning experiences to students due to the systematic implementation of the phase. PBL allows students to gain effective skills for problem-solving through different research and experiences in the education field and to accumulate knowledge through learning, teamwork, different subjects, and disciplines (Sari et al., 2019). Primary goals for PBL in sciences and related courses are to foster clinical reasoning, problem-solving skills, selfdirected learning, communication skills, and deep understanding of concepts and principles in the curriculum (Etherington, 2011), (Rillero, Thibault, Merritt, \& Jimenez-Silva, 2018), (Edwards, Kupczynski, \& Groff, 2019). Through a problembased learning model, students are used to learn from the actual and factual problems in daily life, and students are also used to learn groups and discussions, as well as learn to study issues, seek the relevant information, compile the information obtained, review the existing Solutions alternatives, propose alternative solutions and compose the completion action. So students can understand the theory deeply through an empirical learning practice experience (Malmia et al., 2019), (Wan Nor Fadzilah et al., 2016), (Akçay, 2009), (Zuryanty, Kenedi, Chandra, Hamimah, \& Fitria, 2019).

The activeness of students in the learning process takes various forms of activities, from physical activities that are easily observed to psychological activities that are difficult to observe. In the learning process all this knowledge must be obtained by working independently, with facilities that are created by yourself, both spiritually and technically (Muttaqin \& Raharjo, 2018), (Trianto, 2010). This shows that everyone who learns must be active alone and without activity the learning process is impossible. There are many types of activities that students can do at school, not just listening and taking notes (Education, Jiang, Wang, \& Wang, 2018). Diedrich (2015) was classified the learning activities of students in eight groups, as follows: a) Visual activities such as reading, watching experiments, demonstrations, exhibitions, and watching others work or play, b) Oral activities as posted a fact, connecting such events, ask questions, give advice, express opinions, interviews, discussions, and interruptions. c) Listening activities such dictations, conversations, discussions, music, speeches, and so forth, d) Writing activities such as story writing essays, reports, tests, questionnaires, copying. e) Drawing 
1391 Improving Science Learning Activites And Outcomes By Using Problem Based Learning Model At Elementary School - Ahmad Saleh, Yuni Ahda, Yanti Fitria

DOI: https://doi.org/10.31004/basicedu.v4i4.578

activities such as drawing, making graphs, maps, diagram, patterns, and so on, f) Motor activities like to experiment, make the construction, the model playing, gardening, raise animals, and so on, g) Mental activities as contemplate, remember, solve problems, analyse, look at relationships, decision-making, and so, and h) Emotional activities interested, bored, excited, bold, calm, nervous, and so on (Trianto, 2010).

In this study, only five activities were taken. The activities mentioned above cannot be separated from one another. For example, in every motor activity there is mental activity accompanied by certain feelings and so on. In each lesson various activities can be attempted. However, the activities given to students must be selected and sorted according to the subject matter presented. So it can be concluded that in learning a challenging activity is needed. Without challenging activities, learning will not be successful. Students who are active in learning will get better achievements than students who are less active in learning. Thus student activity is very necessary in learning activities because everything will not be achieved optimally if each student is not active in carrying out an activity.

Learning outcomes are changes in human behaviour from various aspects in the form of knowledge, understanding, habits, skills, appreciation, emotional, social relationships, physical, ethical behaviour, attitudes, and others. Someone who has done an act of learning, there will be a change in one or more aspects of the behaviour (Kamaruddin, 2012), (Nurmalasari et al., 2016). The learning outcomes are the main things in learning. Either in the form of results that can be measured directly with test or non-test. Learning outcomes can be seen in its application in daily life. It consists of understanding concepts (knowledge), process skills, and student attitudes (Amini, Setiawan, Fitria, \& Ningsih, 2019). It can be concluded that learning outcomes are the results obtained by students after the learning process is carried out, both in the form of learning achievement and changes in student behaviour and attitudes. Learning outcomes can be used as a benchmark to determine the level of success of students who have experienced learning. The manifestation of learning behaviour is usually seen in changes in habits, skills, and observations, attitudes and abilities which are usually referred to as learning outcomes.

The purpose to be achieved in this study is to describe the increase in activities and learning outcomes of science learning using the PBL model in grade IV SDN 11 Aur Kuning Bukittinggi, West Sumatra. It is hoped that the results of this research can be useful for teachers in providing knowledge for the development of science education in elementary schools, especially in increasing student activity and learning outcomes with the PBL model. Research results can be used as a refinement of the concept and implementation of science education as a strategic effort in developing the quality of human resources. For schools and related institutions, it becomes a material for consideration for other education practitioners in making educational policies. 
1392 Improving Science Learning Activites And Outcomes By Using Problem Based Learning Model At Elementary School - Ahmad Saleh, Yuni Ahda, Yanti Fitria

DOI: https://doi.org/10.31004/basicedu.v4i4.578

\section{METHOD}

This research generally uses a qualitative approach and is supported by a quantitative approach because the data obtained in this study are not just qualitative data but also quantitative data derived from data on test scores or student learning outcomes. This research is a classroom action research that focuses on efforts to change the current real conditions towards the expected conditions (improvement oriented) (Kunlasomboon, Wongwanich, \& Suwanmonkha, 2015), (Yigit \& Bagceci, 2017). Action research was conducted to increase students' science learning activities and outcomes through the PBL model. This research was conducted collaboratively, meaning that in this study, researchers together with colleagues as collaborative work together in determining problems, planning, acting, observing, and reflecting.

This research was conducted at SD Negeri 11 Aur Kuning Bukittinggi. This research site was chosen based on the results of observations and discussions with colleagues and the Principal of SD Negeri 11 Aur Kuning Bukittinggi to use the PBL model in science learning, especially learning changes in the physical environment and its effects on land. The subjects in this study were 25 students of Class IV SD Negeri 11 Aur Kuning Bukittinggi, consisting of 8 girls and 17 boys. Research data is the result of observing activities and student learning outcomes at the end of each meeting per findings per cycle. Learning outcomes are used to see the increase in student activity and learning outcomes after the action is carried out.
Data from students were obtained through observations when the action was carried out using the observation sheet.

\section{RESULT AND DISCUSSION}

The research was carried out by planning, implementing learning, observing the implementation of learning and reflecting on every action. In every cycle, learning is divided into three activities, namely beginning, core and closing. The result of this research can be described as follows:

Table 1. The Average Value of Each Type of Student Learning Activities

\begin{tabular}{clccc}
\hline No. & $\begin{array}{l}\text { Type of } \\
\text { Activity }\end{array}$ & $\begin{array}{c}1^{\text {st }} \\
\text { Meeting }\end{array}$ & $\begin{array}{c}2^{\text {nd }} \\
\text { Meeting }\end{array}$ & $\begin{array}{c}\text { Improve- } \\
\text { ment }\end{array}$ \\
\hline 1 & $\begin{array}{l}\text { Visual } \\
\text { activities }\end{array}$ & 77 & 86 & $9 \%$ \\
\hline 2 & $\begin{array}{l}\text { Oral } \\
\text { activities }\end{array}$ & 55 & 67 & $12 \%$ \\
\hline 3 & $\begin{array}{l}\text { Writing } \\
\text { activities }\end{array}$ & 38 & 60 & $22 \%$ \\
\hline 4 & $\begin{array}{l}\text { Motor } \\
\text { activities }\end{array}$ & 51 & 71 & $20 \%$ \\
\hline 5 & $\begin{array}{l}\text { Emotional } \\
\text { activities }\end{array}$ & 66 & 78 & $12 \%$ \\
\hline
\end{tabular}

(Source: Primary Data of Research)

From the table above we can see that visual activities increased by $9 \%$ after the second meeting was held. This is because there are 9 out of 25 students who have shown an increase in visual activities than before. This is shown in the activity of watching video shows about the occurrence of abrasion, observing facts on the video, finding problems in the video that is broadcast, working on worksheets, clippings, and articles that are distributed, and looking for data while carrying out investigations. 
1393 Improving Science Learning Activites And Outcomes By Using Problem Based Learning Model At Elementary School - Ahmad Saleh, Yuni Ahda, Yanti Fitria

DOI: https://doi.org/10.31004/basicedu.v4i4.578

Oral activities increased by $12 \%$ after the second meeting was held. This is because there are 12 out of 25 students who have shown an increase in speaking activities (oral activities) than before. This is shown in the question and answer activity about the assignment given, defining the problem of abrasion, collecting facts about abrasion during discussion, presenting responses in proposing temporary answers (hypotheses), reporting the results of the discussion to the class, giving responses to other group reports, concluding lessons, and carry out learning reflection activities. Students' oral activities are still weak because their speaking ability when submitting facts about the issues being discussed is still limited. This is because the stages of the PBL model are still unfamiliar to students because so far the teacher has never carried out this kind of learning stage. Teachers have not provided opportunities for students to ask the facts they got during the learning process. Supposedly, the teacher bridges the needs of students during learning, because the PBL model actually provides the widest possible opportunity for students to satisfy their curiosity. This is in accordance with the opinion of Akçay which states that "the roots of problem-based learning can be based on the progressive movement, especially on John Dewey's beliefs that teachers should teach by tempting to students" natural instincts to investigate and create (Akçay, 2009).

Writing activities increased by $22 \%$ after the second meeting was held. This is because there are 22 out of 25 students who have shown an increase in writing activities than before. This is because at the first meeting there were still many students who had not shown writing activity because the teacher had not maximally facilitated students to write down discussion activities in each group. Writing activities at the first and second cycle meetings also did not show a good improvement. This is because teachers have not facilitated all students with media or learning tools, such as worksheets and articles. All of these media were only distributed by the teacher one for each group. So that those involved in writing activities are only students who fill out the worksheets. Likewise with other types of writing activities, it can be said that in this first cycle students' writing activities still did not show a maximum increase. For this reason, based on the reflection carried out, at the next meetings the teacher understands better the obstacles faced so that the teacher will better facilitate all the learning needs needed by each student so that all students are actively involved in writing activities. This is in accordance with the opinion of Etherington which states that PBL empowers students and educators to take responsibility for directing learning, defining and analysing problems and building solutions. Getting students to work on solutions to problems faced by stakeholders provides all parties involved in the process with a framework for expanding learning opportunities. Problem-based learning guides students to useful facts and concepts that will never be discovered before. Finally, problembased learning helps cultivate strategic learners and problem solvers who can work with local communities as innovators and pioneers of 
1394 Improving Science Learning Activites And Outcomes By Using Problem Based Learning Model At Elementary School - Ahmad Saleh, Yuni Ahda, Yanti Fitria

DOI: https://doi.org/10.31004/basicedu.v4i4.578

productive and progressive education (Etherington, 2011).

Motor activities increased by $20 \%$ after the second meeting was held. This is because there are 20 of the 25 students who have shown an increase in movement activity from before. This is shown in the activity of conditioning the room for learning activities, collecting facts about abrasion during discussions, and moving to form study groups. Emotional activities increased by $12 \%$ after the second meeting was held. This is because there are 12 out of 25 students who have shown increased emotional activities than before. This is shown in terms of passion, enthusiasm, and joy when the teacher communicates learning objectives, carries out investigations, and when activities conclude problem-solving solutions.

This classroom action research is not only done to increase learning activities, but also to improve students' science learning outcomes. The lecture method that has been predominantly used by the teacher is reduced and interspersed with the PBL model. After conducting classroom action research through two cycles and four meetings, it was seen that there was a good increase in student learning outcomes as follows.

Table 2. Average Value of Student Learning Outcomes

\begin{tabular}{clccc}
\hline No. & $\begin{array}{c}\text { Learning } \\
\text { Outcomes }\end{array}$ & $\begin{array}{c}\text { Pre-Action } \\
\left(1^{\text {st }}\right. \\
\text { Meeting) }\end{array}$ & $\begin{array}{c}\text { Post- } \\
\text { Action } \\
\left(2^{\text {nd }}\right. \\
\text { Meeting }\end{array}$ & $\begin{array}{c}\text { Improve- } \\
\text { ment }\end{array}$ \\
\hline 1. & Cognitive & 52 & 72 & $20 \%$ \\
\hline 2. & Affective & 60 & 74 & $14 \%$ \\
\hline 3. & $\begin{array}{l}\text { Psycho- } \\
\text { motor }\end{array}$ & 61 & 77 & $16 \%$ \\
\hline
\end{tabular}

(Source: Primary Data of Research)
Based on the table above can be shown that the cognitive aspect of learning outcomes has increased by $20 \%$ from before the action was taken. This is because there were 20 students who showed an increase in learning outcomes in the cognitive aspects after the first cycle of action was held. Before the action was taken, the class average number was 69.36 , and after the action was taken, the class average number increased to 73.12. The highest score of students before the action was taken was 90 and after the action was taken it increased to 95 . The lowest score of students before the implementation of the PBL model was 45 and after implementing the PBL model at the first and second meetings the student learning outcomes increased to 50 . If seen in the results of class completeness, there was a satisfactory improvement, where before the action was taken there were only 13 students who achieved the minimum completeness standard, while after the PBL model was applied in the learning process there were 18 students who obtained the minimum completeness standard, while 7 other students had not reached the completeness standard minimal. When compared to the percentage acquisition of class completeness before the PBL model was applied and after the PBL model was applied in the classroom, the percentage ratio was from 52 to 72 . This statement is supported by Sarya's opinion which states that activities in PBL facilitate the occurrence of (1) exploration of the relationship of meaning to understanding, (2) the process of manipulating information (learning material) through a series of analysis of a synthesis will cause students to think 
1395 Improving Science Learning Activites And Outcomes By Using Problem Based Learning Model At Elementary School - Ahmad Saleh, Yuni Ahda, Yanti Fitria

DOI: https://doi.org/10.31004/basicedu.v4i4.578

critically, so that students' science learning outcomes can improved (Sarya, Suarni, Adnyana, \& Suastra, 2019).

Learning outcomes in the affective aspect increased by $14 \%$ after the second meeting was held. This is because 14 students showed an increase in learning outcomes in the affective aspects after the first cycle of action was implemented. Attention of students to lessons increased by $16 \%$ after the second meeting was held. This is because there are 16 out of 25 students who have shown increased attention than before. Participation in groups increased by $16 \%$ after the second meeting was held. This is because there are 16 out of 25 students who have shown an increase in participation from before. The courage to express opinions has increased by $10 \%$ after the second meeting was held. This is because there are 10 out of 25 students who have shown increased courage from before. By using the PBL model, the affective aspects of students also increased even though the increase was not significant. This is in accordance with the opinion of Michael (2004) who states that PBL is an instructional method where relevant problems are introduced at the beginning of the instruction cycle and used to provide the context and motivation for the learning that follows (Aktamiş, Hiğde, \& Özden, 2016); (Argaw, Haile, Ayalew, \& Kuma, 2017); (Edwards et al., 2019).

Learning outcomes in the psychomotor aspect increased by $16 \%$ from the previous one. This is because there are 16 students who have shown an increase in learning outcomes in the psychomotor aspects after the first cycle of action.
Timeliness increased by $14 \%$ after the second meeting was held. This is because there are 14 out of 25 students who have shown improvement from before. The work order accuracy increased by $16 \%$ after the second meeting was held. This is because there are 16 out of 25 students who have shown improvement from before. The ability to work together has increased by $17 \%$ after the second meeting was held. This is because there are 17 out of 25 students who have shown improvement from before. Assessment of psychomotor aspects is in the sufficient category. This can be seen in the activities of the majority of students who use sufficient and inappropriate time, insufficient and inaccurate work order, and sufficient and less able to cooperate. The improvement in the psychomotor aspects of these students was supported by Rillero's opinion which stated that in ProblemBased Learning (PBL), a problem is posed before students have learned how to solve it. Students' skills and PBL pairs well for effective learning environments (Rillero et al., 2018).

The implementation of learning with the PBL model is already in the very good category. However, even so, there are still some descriptors from the implementation stages of the PBL model that have not yet appeared. The fact-gathering stage has not been carried out optimally, where the teacher has not guided students who have difficulty finding facts about the issues being discussed. There is a concern that at the next meeting there will still be students who submit facts that are not appropriate and not related to the issues being discussed. The stage of conducting the investigation has not been carried out 
optimally, where the teacher has not given the opportunity to students to ask about the steps of the investigation that they have not understood. It is feared that at the next meeting there will still be students who carry out their investigations not as expected so that the work order is not correct.

\section{CONCLUSSION}

Based on the discussion of this research, it can be seen that the use of the PBL model in science learning in class IV SDN 11 Aur Kuning Kota Bukittinggi is very effective because it can increase activities and science learning outcomes, making students active, creative, and happy in learning. PBL also invites students to take part in developing new concepts that are useful in everyday life in learning, so that learning is more meaningful. Learning is more centred on students physically and psychologically in the learning process so that the knowledge conveyed is easier to understand and can be implicated in everyday life. This study provides findings to provide input for researchers that the use of the PBL model in science learning is in accordance with the curriculum recommended by the government.

\section{REFERENCES}

Akçay, B. (2009). Problem-based learning in science education. Journal of Turkish Science Education, 6(1), 26-36.

Aktamiş, H., Hiğde, E., \& Özden, B. (2016). Effects of the inquiry-based learning method on students' achievement, science process skills and attitudes towards science: A metaanalysis science. Journal of Turkish Science Education, 13(4), 248-261. https://doi.org/10.12973/tused.10183a

Amini, R., Setiawan, B., Fitria, Y., \& Ningsih, Y.
(2019). The difference of students learning outcomes using the project-based learning and problem-based learning model in terms of self-efficacy. Journal of Physics: Conference $\quad$ Series, $1387(1)$. https://doi.org/10.1088/17426596/1387/1/012082

Argaw, A. S., Haile, B. B., Ayalew, B. T., \& Kuma, S. G. (2017). The effect of problem based learning (PBL) instruction on students' motivation and problem solving skills of physics. Eurasia Journal of Mathematics, Science and Technology Education, 13(3), 857-871.

https://doi.org/10.12973/eurasia.2017.00647a

Dwi, I. N., \& Anitah, S. W. (2018). The Implementatyion Off Problem Based Learning Model (PBL) on Teachers and Students Grade Five Elementary Schools in Surakarta City. International Journal of Active Learning, 3(2), 116-123. Retrieved from http://journal.unnes.ac.id/nju/index.php/ijal

Education, T., Jiang, T., Wang, S., \& Wang, J. (2018). Effect of Different Instructional Methods on Students ' Conceptual Change Regarding Electrical Resistance as Viewed from a Synthesized Theoretical Framework, 14(7), 2771-2786.

Edwards, D. J., Kupczynski, L., \& Groff, S. L. (2019). Learning styles in problem-based learning environments impacts on student achievement and professional preparation in university level physical therapy courses. International Journal of Higher Education, $8(3)$, 206-213. https://doi.org/10.5430/ijhe.v8n3p206

Etherington, M. (2011). Investigative primary science: A problem-based learning approach. Australian Journal of Teacher Education, 36(9), 36-57. https://doi.org/10.14221/ajte.2011v36n10.1

Juleha, S., Nugraha, I., \& Feranie, S. (2019). The Effect of Project in Problem-Based Learning on Students' Scientific and Information Literacy in Learning Human Excretory System. Journal of Science Learning, 2(2), 33. https://doi.org/10.17509/jsl.v2i2.12840

Kamaruddin, S. A. (2012). Character Education 
1397 Improving Science Learning Activites And Outcomes By Using Problem Based Learning Model At Elementary School - Ahmad Saleh, Yuni Ahda, Yanti Fitria

DOI: https://doi.org/10.31004/basicedu.v4i4.578

and Students Social Behavior, 6, 223-230.

Kunlasomboon, N., Wongwanich, S., \& Suwanmonkha, S. (2015). Research and Development of Classroom Action Research Process to Enhance School Learning. Procedia - Social and Behavioral Sciences, 171, 1315-1324. https://doi.org/10.1016/j.sbspro.2015.01.248

Malmia, W., Makatita, S. H., Lisaholit, S., Azwan, A., Magfirah, I., Tinggapi, H., \& Umanailo, M. C. B. (2019). Problem-based learning as an effort to improve student learning outcomes. International Journal of Scientific and Technology Research, 8(9), 1140-1143. https://doi.org/10.5281/zenodo.3457426

Murni Eva Marlina. (2013). Kurikulum 2013 Yang Berkarakter. Jurnal JUPIIS 2085-482X, Vol 5(No 2), 27-38. Retrieved from http://jurnal.unimed.ac.id/2012/index.php/jup iis/article/view/1112

Muttaqin, M. F., \& Raharjo, T. J. (2018). The Implementation Main Values of Character Education Reinforcement in Elementary School, 7(1), 103-112.

Nurfidianty, A., Ashadi, \& Mulyani, S. (2015). Pengembangan Lembar Kegiatan Peserta Didik Berbasis Inkuiri Terbimbing Pada Materi Termokimia Kelas Xi Sma/Ma. Jurnal Inkuiri, 4(3), 21-28.

Nurmalasari, R., Dian, R., Wati, P., Puspitasari, P., Diana, W., \& Dewi, N. K. (2016). Peran Guru Dalam Implementasi Kurikulum 2013. Jurnal Berkala Program Pascasarjana UM Malang, 722-733. https://doi.org/10.1063/1.3499372

Rillero, P., Thibault, M., Merritt, J., \& JimenezSilva, M. (2018). Bears in a boat: Science content and language development through a problem-based learning experience. Science Activities: Classroom Projects and Curriculum Ideas, 8121, 1-6. https://doi.org/10.1080/00368121.2017.1406 323

Sari, R. N., Ahda, Y., Fitria, Y., Padang, U. N., Padang, U. N., \& Padang, U. N. (2019). Effectiveness of Guided Inquiry Learning Model and Problem Based Learning Model on Thematic, 1(2), 257-264.
Sarya, I. W., Suarni, N. K., Adnyana, I. N. B., \& Suastra, I. W. (2019). The effect of problem based learning and authentic assessment on students' natural science learning outcome by controlling achievement motivation. Journal of Physics: Conference Series, 1318(1). https://doi.org/10.1088/17426596/1318/1/012095

Trianto. (2010). Mendesain Model Pembelajaran Inovatif-Progresif. Jakarta: KENCANA.

Wan Nor Fadzilah, W. H., Nurazidawati, M. A., Oziah, O., Lilia, H., Mohamad Sattar, R., Kamisah, O., \& Zanaton, I. (2016). Fostering Students' 21st Century Skills through Project Oriented Problem Based Learning (POPBL) in Integrated STEM Education Program. Asia-Pacific Forum on Science Learning and Teaching, 17(1), 1-19.

Widya Sukmana, R. (2018). Pendekatan Science, Technology, Engineering and Mathematics (Stem) Sebagai Alternatif Dalam Mengembangkan Minat Belajar Peserta Didik Sekolah Dasar. Pendas : Jurnal Ilmiah Pendidikan Dasar, 2(2), 189. https://doi.org/10.23969/jp.v2i2.798

Yigit, C., \& Bagceci, B. (2017). Teachers' opinions regarding the usage of action research in professional development. Journal of Education and Training Studies, $5(2)$, 243. https://doi.org/10.11114/jets.v5i2.1878

Zuryanty, Kenedi, A. K., Chandra, R., Hamimah, \& Fitria, Y. (2019). Problem based learning: A way to improve critical thinking ability of elementary school students on science learning. Journal of Physics: Conference Series, 1424(1). https://doi.org/10.1088/1742$6596 / 1424 / 1 / 012037$ 